\title{
A Caverna Do Diabo: O ensaio romântico de Valeriano De Souza e as religiões afrobrasileiras em Alagoas, no séc. XIX
}

Santos, Irineia M. Franco dos

História - Universidade Federal de Alagoas

irineiafranco@gmail.com

Para Wilson do Nascimento Barbosa

\begin{abstract}
Resumo:
O objetivo deste artigo é apresentar uma reflexão inicial sobre o processo de constituição histórica das religiões afrobrasileiras em Alagoas, no século XIX. Para isso, utilizar-se-á como guia o folhetim "A Caverna do Diabo: ensaio romântico", de Valeriano de Souza, publicado no jornal O Orbe, em diferentes edições no ano de 1884 . Destaca-se ali, a ideologia da intelectualidade alagoana sobre os escravos, africanos e suas práticas mágico-religiosas. Também se problematiza o processo de constituição de uma identidade cultural local, permeada por concepções racistas e de demonização do "Outro", que tendeu a se intensificar em fins do XIX e no Pós-Abolição. Por fim, busca-se estabelecer hipóteses de interpretação sobre a formação dos xangôs alagoanos que poderão contribuir com as novas pesquisas que surgem sobre o tema.
\end{abstract}

Palavras-chave: Religiões afro-brasileiras, Alagoas, século XIX.

\section{LA CUEVA DEL DIABLO: EL ENSAYO ROMÁNTICO DE VALERIANO DE SOUZA Y RELIGIONES AFROBRASILEÑAS EN ALAGOAS, EN EL SIGLO XIX}

\section{Resumen:}

El objetivo de este trabajo es presentar una reflexión inicial sobre la constitución histórica de las religiones afrobrasileñas en Alagoas, en el siglo XIX. Para ello, se utilizará como guía el folletín "La Cueva del Diablo: ensayo romántico" por Valeriano de Souza, publicado en la revista The Orb, en diferentes ediciones en 1884. Se destaca allí, la ideología de la intelectualidad Alagoana sobre los esclavos, los africanos y sus prácticas mágico-religiosas. También se explica el proceso de creación de una identidad cultural local, las concepciones impregnadas por el racismo y la demonización del "otro", que tiende a intensificarse en los finales del siglo XIX y Post-Abolición. Por último, se tratará de establecer hipótesis sobre la formación de alagoanos xangôs que podrían contribuir a la investigación que puedan surgir sobre el tema.

Palabras clave: africano-brasileños Religión, Alagoas, siglo XIX.

\section{APRESENTAÇÃO DA BASE TEÓRICA, HIPÓTESES E FONTES}

"O espírito não pode viver fora da matéria e, se essa lhe falta, ele faz uma nova. O marxismo teve razão em nos alertar contra o idealismo, 
lembrando que não há vida social e cultural possível fora da matéria que a condiciona; seu erro foi crer que ela nasce sempre da matéria. Não devemos, ao contrário, esquecer este poder de criação das correntes profundas da alma coletiva”. (Bastide, 1960: 32)

As religiões de matriz africana são objetos privilegiados para se conhecer os elementos profundos da "visão de mundo" negro-brasileira e sua materialização cultural e social. A perspectiva histórica sobre uma determinada religião busca levantar a relação estabelecida ao longo do tempo entre a criação ou recriação de determinadas crenças religiosas articuladas à vida social, cultural e política dos seus locais de origem. A citação acima de Roger Bastide problematiza a aplicação de certa leitura marxista sobre as religiões e apresenta o interessante viés de se perceber a capacidade criadora vinculada às ideologias religiosas, "correntes profundas da alma coletiva”. A crítica sociológica de Bastide dirige-se, por outro lado, ao método histórico como um todo ao afirmar que o estudo das trocas culturais pelos historiadores é feito "destacando a individualidade de cada caso", não tentando "com auxílio do método comparativo, construir uma tipologia, ou no mínimo, um esquema conceitual permitindo passar da descrição à explicação" (Bastide, 1960: 24). De fato, os historiadores da cultura negra no Brasil tenderam a aprofundar estudos de caso específicos sobre diferentes locais, destacando as características e experiências exemplares. Cabe ressaltar, porém, que dos anos 1960 (época do texto de Bastide) até a atualidade houve uma renovação intensa nos estudos históricos sobre as religiões negras, com a aplicação não somente do método comparativo como também do levantamento de novas fontes históricas para o estudo tanto dos séculos passados, como do período contemporâneo. A História conseguiu ampliar seus objetos e historicizar a experiência das populações negras e indígenas. As bases teórico-metodológicas para a constituição de uma teoria explicativa geral sobre as religiões afrobrasileiras têm-se apresentado com mais clareza. Seguindo estas ideias iniciais, espera-se neste artigo levantar alguns problemas a partir de um texto literário específico.

O uso da literatura como fonte para a história está consagrado há várias décadas. Porém, os cuidados teórico-metodológicos parecem ser constantemente lembrados, uma vez que a clareza no seu uso ainda traz constantes desafios ao historiador. Parto das observações apresentadas pelos mestres Cardoso e Vainfas, quando estes afirmam sua "profissão de fé". Para eles considerar o conteúdo histórico do texto independente de sua forma não implicaria, "reduzir a história ao texto, a exemplo do que fazem os autores estruturalistas ou pósestruturalistas, que negam haver história fora do discurso". Ao contrário, para estes historiadores,

"trata-se, antes, de relacionar texto e contexto: buscar os nexos entre as ideias contidas nos discursos, as formas pelas quais elas se exprimem e o conjunto de determinações extratextuais que presidem a produção, a circulação e o consumo dos discursos. Em uma palavra, 
o historiador deve sempre, sem negligenciar a forma do discurso, relacioná-lo ao social” (Cardoso; Vainfas, 1997: 378).

Mesmo considerando que "a história é sempre texto, ou mais amplamente discurso", Cardoso e Vainfas esclarecem que "somente através da decifração dos discursos que exprimem ou contém a história poderá o historiador realizar o seu trabalho". Pareceria, para eles, válida, a observação de Eliseo Verón de que no funcionamento de uma sociedade, "nada é estranho ao sentido: o sentido está, portanto, em toda parte", do mesmo modo que "o ideológico e o poder estão sempre em toda parte". Ou seja, concorda-se que "todo fenômeno social é suscetível de ser lido em relação ao ideológico e em relação ao poder”. E, segundo ainda Verón, citado por eles, as "condições de produção" de um discurso têm a ver com o "ideológico", com os valores da sociedade que o produz; ao passo que as "condições de seu reconhecimento" dependem do poder, isto é, das "instâncias capazes de legitimar ou não a sua aceitação na sociedade" (Cardoso; Vainfas, 1997: 378).

Elegeu-se, portanto, a análise temática como método para verificar a formação de discursos que justificaram práticas racistas em relação à religiosidade afrobrasileira em Alagoas no século XIX, e que foram continuamente reforçadas no século XX. Isto consistirá em "descobrir os núcleos de sentido que compõem a comunicação e cuja presença, ou frequência ou aparição podem significar alguma coisa para o objetivo analítico escolhido" (Cardoso; Vainfas, 1997: 382).

Sabe-se que, a respeito da formação histórica das religiões afrobrasileiras, os séculos XVIII e XIX são, atualmente, os mais buscados pelos historiadores e outros especialistas, uma vez que a quantidade de fontes disponíveis e conhecidas tem-se ampliado. Encontram-se nas fontes eclesiásticas, como os autos de inquisição, informações sobre os cultos organizados e as práticas da dita feitiçaria africana, numa mistura de crenças africanas (substrato mais forte), bruxaria europeia, esoterismo judaico e cigano e pajelança indígena. Ocorreram três visitações do Santo Ofício ao Brasil entre 1590 e 1780. A primeira foi à Bahia e Pernambuco em 1591 e acusou um grande número de negros, escravos e forros de praticar "feitiçaria". O mesmo ocorreu na segunda visitação em 1618 à Bahia, Grão-Pará e Maranhão. A última visitação permaneceu por mais tempo, foi ao Grão-Pará, prolongando-se de 1763 a 1769. Havia aí uma "preocupação" com a "manifestação e perpetuação dos cultos africanos no Brasil” (Moura, 2001: 210). ${ }^{1}$

Muitos processos inquisitoriais e criminais tiveram lugar nas Colônias portuguesas e acusaram homens e mulheres. Em 2008, o pesquisador Luiz Mott publicou em artigo uma lista

\footnotetext{
${ }^{1}$ Até o momento não foram encontrados processos inquisitoriais sobre feitiçaria para a região de Alagoas. Mesmo havendo processos para Pernambuco, a parte sul da capitania, não aparece nesses autos, constando, na maioria das fontes abordadas pelos especialistas processos de bigamia. Para maiores informações: MOTT, Luiz. Bígamos de Alagoas nas garras da Inquisição. Revista Ultramares, $\mathrm{N}^{\mathrm{O}}$ 1, vol. 1, Jan./Jul. 2012, pp.8-43. Disponível em: http://www.revistaultramares.com/. Data de acesso: 25/o3/2013.
} 
(sumário comentado com hipóteses interpretativas) de cerca de vinte documentos encontrados por ele no Arquivo da Torre do Tombo em Portugal. Entre eles, os processos de Francisco Manicongo e Domingos Umbata apoiavam a hipótese da existência, para aquele período inicial, de sacerdotes africanos atuando na Colônia. Também traz vários informes sobre os processos de feitiçaria na América, África e em Portugal, dos séculos XVI ao XVIII. Como o processo de Luzia Pinta de 7 de junho de 1739, conhecido pelo trabalho de Laura de Mello e Souza, e exemplar por trazer o relato mais detalhado conhecido de um processo inquisitorial referente às práticas afrobrasileiras no período. ${ }^{2}$

O fim da escravidão (1888) e o processo de urbanização e estruturação do modo de produção capitalista no Brasil em fins do século XIX e início do XX, configurou um novo ambiente para o desenvolvimento das religiões afrobrasileiras. As perseguições que sempre existiram sobre esses cultos foram sistematizadas a partir de novas legislações que tinham por objetivo "higienizar" as cidades e modernizar os centros metropolitanos brasileiros. Os espaços de socialização dos ex-escravos e seus descendentes foram gradativamente diminuídos. A população que estivera escravizada começou, nesse período, a ser empurrada para as periferias e favelas. O racismo vigente transpareceu nas leis de terras, nos projetos de imigração de europeus que ocupavam os postos de trabalho nas grandes cidades, na discriminação no acesso à educação, nos códigos de conduta e penais, etc. A proposta política do "branqueamento", era então discutida pelos senadores e justificada pelas teorias racialistas em voga na Europa.

No que diz respeito às religiões afrobrasileiras se, por um lado, tem-se uma ampliação e novas "ressignificações", como no caso da Umbanda, por outro, tem-se um acirramento das velhas perseguições, quebras de terreiro, prisões e espancamento de sacerdotes. O episódio da invasão dos terreiros de Xangô em Maceió em 1912 é exemplar da complexidade das relações político-sociais no período da República Velha. ${ }^{3}$ Foi em fins do XIX e início do século XX que algumas das "nações" religiosas existentes hoje tiveram a fundação de suas casas matrizes e a expansão delas pelo território nacional. Principalmente, aquelas da região nordeste do país, historicamente as mais antigas.

A intenção aqui é apresentar alguns elementos que contribuam para identificar a historicidade da experiência específica da região alagoana e inserí-la no conjunto das transformações que ocorreram no território nacional. Considera-se essencial procurar identificar por meio de fontes variadas as possíveis soluções (hipóteses) ao problema da formação histórica do xangô em Alagoas neste período. Por enquanto, não foi possível confirmar, com total segurança, uma "casa matriz" específica que tenha iniciado suas atividades

\footnotetext{
${ }^{2}$ Conf. SOUZA, Laura de Mello e. O Diabo e a Terra de Santa Cruz: feitiçaria e religiosidade popular no Brasil Colonial. $2^{\mathrm{a}}$ edição. São Paulo: Companhia das Letras, 2009.

3 O evento conhecido como Quebra de Xangô, ocorrido em 1912, foi traumático para a continuidade das religiões afrobrasileiras naquela cidade. O trabalho mais completo sobre o Quebra é a tese publicada do antropólogo Ulisses Neves RAFAEL, sob o título "Xangô Rezado Baixo: religião e política na Primeira República”. Maceió: Edufal, 2012. O resgate histórico desse evento, a partir de 2007 , foi importante para ampliar as pesquisas sobre a temática da religiosidade negra em Alagoas.
} 
ainda em fins do século XIX. Na tradição oral dos xangôs de Maceió, diz-se que o Terreiro de Tia Marcelina, teria sido o primeiro a ser fundado na cidade, no final do século XIX. Esta iyalorixá foi morta em consequência da violência do "Quebra-Quebra" em 1912. Na falta de maiores detalhes para esta informação, as fontes encontradas até o momento sugerem que houve um contexto favorável de formação e organização da religiosidade africana local, em um processo elaborado de sincretismo com as tradições indígenas e católicas, tanto no interior como na capital Maceió, já no início dos oitocentos. É possível que casas de axé tenham chegado a existir, neste período.

As fontes conhecidas também indicam o imbricamento do que se convencionou chamar "folclore negro das Alagoas" (A. Duarte, M. Diégues Júnior, T. Brandão) com a religião africana e a católica. Ou seja, a experiência histórica do negro alagoano relaciona-se à elaboração de uma cultura negra específica de sua região em condições de vida difíceis, elaborada no tempo, modificada e, de certa forma, consolidada entre o período da dominação escravocrata e o da subalternização como trabalhador livre. A ideologia negra da quilombagem (A. Nascimento) também surge nas fontes ao se perceber a forte presença de um ideário de liberdade vinculado à memória do Quilombo dos Palmares (c.1580 a 1710), tanto positivamente na mentalidade popular, quanto negativamente na das elites.

O período aqui estudado é o século XIX, em especial a segunda metade, antes da Abolição da escravatura. Como se sabe, a região alagoana tornou-se independente de Pernambuco em 1817. A sua elite política e proprietária de terras, juntamente com a Igreja Católica, mantiveram-se ao lado da monarquia portuguesa em diferentes momentos de revoltas e rebeliões populares, numa relação de alianças desde a Guerra dos Holandeses e contra Palmares no século XVII. Apesar desta "união geral" contra as "ameaças" externas e internas, essa elite ficou conhecida nacionalmente por sangrentas lutas entre suas famílias principais, para a manutenção de poder local e privilégios. Sabe-se que toda identidade cultural também é política, no sentido de servir como elaboração intelectual e justificativa de relações sociais entre grupos e classes, portanto, ideológica. As elites em Alagoas tiveram por muito tempo o privilégio de escrever a história local, de acordo com seus interesses. Seriam eles: (a) justificar o domínio da terra e das forças produtivas; e (b) manter o controle sobre a força de trabalho, o território e o privilégio dos mecanismos de poder institucionais: políticos, jurídicos, legislativos. Como afirmado, apesar de haver certa "unidade" nessas intenções gerais, muitas vezes os interesses familiares levaram a lutas no seio dessa elite, que por sua vez, mantinham seus próprios grupos populares subalternos, lutando ao seu lado.

Entre a necessidade de organizar internamente o processo produtivo da província e o controle de sua população, a elite alagoana no XIX procurou também inserir-se nos movimentos intelectuais de seu tempo. O Instituto Histórico, Archeológico e Geográfico de Alagoas4 foi

${ }_{4}^{4}$ Hoje Instituto Histórico e Geográfico de Alagoas (IHGAL). 
fundado pelo então presidente da província José Bento da Cunha Figueiredo Júnior, em 2 de dezembro de 1869. A partir daí, uma historiografia oficial passou a ser produzida e divulgada no reforço da invenção de uma identidade alagoana - branco-europeia, escravagista e católica. Seria tal identidade a ilusão de uma autoimagem de ocidentalidade, negadora de sua própria dinâmica cultural. O eixo interpretativo desta historiografia oficial girou (e, talvez continue) em torno de três eventos: (a) A guerra contra os Holandeses (1595-1663), (b) a guerra de Palmares (1695) e (c) a guerra dos bárbaros (1688). Podem-se incluir, também, os estudos sobre a ocupação do território e a produção açucareira, com destaque para os engenhos.

A fonte aqui destacada é exemplar para esta discussão.5 Valeriano de Souza tentou repensar a história local, apresentando os temas que foram, a partir do XIX, consagrados na literatura romântica brasileira. O primeiro surge ao descrever a natureza local, e a figura do "gentio brasileiro".

Estamos em pleno mês de dezembro de 1882. Aborrecido da vida escravizada da cidade empreendi uma viagem de recreio pelo centro da nossa fértil província de Alagoas. (...) Entregue a esta torrente de pensamentos que assaltam sempre o viajante no meio das estradas desertas, lembrava-me que devia ser de uma maravilha pavorosa as nossas matas antes do machado civilizador ter nela penetrado. Lembrava-me da dor que devia ter o gentio brasileiro se visse estes lugares queridos devastados pelos brancos, suas matas derribadas e seus campos sagrados transformados em povoados, vilas e cidades. Sentia-me indignado com a civilização. A meu ver nada tinha de poético essas matas frondosas derribadas, insultadas e humilhadas por essa locomotiva, cavalo de ferro da civilização moderna. Desejava ser gentio; no meio de minha indignação parecia-me já trincar nos afilados dentes as carnes quentes dos malvados brancos, com especialidade os ingleses, profanadores do santuário da criação.

Despertado da minha meditação pela voz rouquenha do meu guia ri-me dos desacertos de meu pensamento. Desejar ser gentio era uma coisa engraçada e ainda mais antropófago, querer agasalhar no estômago todo mundo civilizado, só da cabeça de um viajante que monta um cavalo magro! 6

\footnotetext{
5 O jornal $O$ Orbe, está disponível no site da Biblioteca Nacional. Ali estão acessíveis vários números que vão de 1879 a 1900. Entre a variedade de assuntos encontrados destacam-se, em primeiro lugar, anúncios de fuga de escravos como o que segue: "ESCRAVOS FUGIDOS. Fugiram do engenho Frecheiras, na ribeira do Gautuba os escravos seguintes (...). Balbino, casado, nação costa, bastante ladino, altura regular, já tem cabelos brancos, trabalha de carpina e perfeitamente em qualquer maquina de engenho; inculca-se curandeiro e costuma andar manco proveniente de cravos nos pés. Saiu no mês de março com sua mulher. Bernarda, crioula, representa ter 50 anos, alta, fula, tem a cicatriz de um talho na testa; levou em sua companhia uma neta liberta de 2 anos mais ou menos. Saíram daqui dizendo que tinham que embarcar para Pernambuco ou Ceará, porque existia em Maceió um navio para os conduzir por ordem do governo. (...) José Marinho de Alcântara Lima”. O ORBE, Maceió, domingo, 13 de janeiro de 1884, Ed. 1, p. 2. Biblioteca Nacional, Hemeroteca Digital Brasileira. Disponível em: http://memoria.bn.br/hdb/periodico.aspx. Data de acesso: 07/11/2012.
}

${ }^{6}$ O ORBE, Maceió, domingo, 13 de janeiro de 1884, Ed. 1, p. 2. Biblioteca Nacional, Hemeroteca Digital Brasileira. Disponível em: http://memoria.bn.br/hdb/periodico.aspx. Data de acesso: 07/11/2012. 
A indignação de Arthur com a "civilização" e o "branco", em favor das matas, da natureza e dos nativos, é ironizada pela personagem, ao rir do seu disparate ao se imaginar antropófago. O avanço da "civilização" seria inevitável. É interessante notar que, em seu ensaio, as duas personagens que se permitem refletir sobre a história local, são estudantes, um já "doutor", Alfredo. Esse pequeno exemplo serve para demarcar os sentidos de oposição que percorrem todo o ensaio de Valeriano de Souza: "ignorância/superstição x conhecimento"; “civilização x barbárie”.

Antes de adentrar no estudo de caso, vale ressaltar que nos oitocentos uma rigorosa legislação municipal, através das "posturas das Câmaras" pôs-se a proibir e/ou regular as práticas culturais negras em Alagoas. Até o momento, foram identificados proibições desde 1839.7 A maioria delas reprime os chamados "batuques" nas vilas e zonas rurais, coibindo diretamente a prática religiosa negra. As penas variavam por localidade podendo ser prisão, pagamento de multa ou castigos físicos; quando não, uma variação delas, prevalecendo multa e prisão. Vê-se abaixo:

\section{Resolução no 10 de 11 de julho de 1839 - Posturas municipais da cidade das Alagoas}

Art. $2^{\mathrm{o}}$ "Ficam prohibidos os batuques e danças indecentes com vozerias, e bebidas espirituosas: penas de dous mil réis e dous dias de prisão, ficando o dono da casa que for compreendido na infração deste artigo, incurso mais no dobro da multa". (...)

Art. $11^{\circ}$. Fica prohibido o bárbaro e imoral espetáculo denominado Quilombo. Os contraventores sofrerão a pena de oito dias de prisão e multa de dous mil réis, sendo pessoas escravas serão seus senhores que pagarão a multa somente. (...)

\section{Lei no 94 de 31 de julho de 1848: approva posturas municipaes da camara de Porto Calvo, p. 462.}

(...)

Art. 23. São absolutamente prohibidos os batuques, danças e ajuntamentos de escravos, em qualquer lugar ou hora: pena de duas a quatro dúzias de bolos em cada um. ${ }^{8}$

Tem-se, portanto, um ambiente social claramente repressor da culturalidade negra. Pela grande quantidade de posturas que se repetem e por seu prolongamento no tempo - a última identificada com essas características data de 1854 - pode-se inferir que, apesar do ambiente

\footnotetext{
7 Interessante que em 1839 deu-se a transferência da capital, da cidade de Alagoas para Maceió. A partir daí, percebe-se o aumento das regras para ordenação do espaço urbano da nova capital.

8 COMPILAÇÃO das Leis Provinciaes das Alagoas - volume 1, p. 357. Talvez o aumento dessas proibições esteja relacionado às rebeliões escravas na Bahia, a chamada Revolta dos Malês de 1835. Sabe-se que vários escravos fugidos daquele estado, que entraram em Alagoas através de Penedo. A exploração articulada dessas fontes ainda está por ser feita.
} 
hostil, os negros em Alagoas conseguiram manter a recriação da religiosidade africana na região. Marcando, inclusive, a criação de cultura popular original, extremamente diversificada e rica que circulava entre o sagrado e o profano. O "imoral Quilombo", por exemplo, é uma dança dramatizada, apresentada por populares que fazem uma "representação" da guerra de Palmares, em que lutam em lados opostos negros e índios. No jornal O Orbe, há várias menções a este "folguedo" que era, no período das festas natalinas, apresentado na capital e no interior. Também nas festas de irmandades, principalmente nas de Nossa Senhora do Rosário, era apresentado como parte das celebrações. 9

\section{A CAVERNA DO DIABO: ANÁLISE TEMÁTICA E IDEOLOGIA SOCIAL}

O folhetim "A Caverna do Diabo: ensaio romântico" foi publicado no jornal O Orbe entre 13 de janeiro e 19 de março de $1884 .{ }^{10}$ Seu autor, Valeriano de Souza (Tibúrcio Valeriano de Souza Rodrigues) era irmão do jornalista Carlos Rodrigues, responsável pela tipografia de $\mathrm{O}$ Orbe, e também articulista do jornal ${ }^{11}$. Não foi possível encontrar informações mais precisas sobre Valeriano. Sabe-se que era bem jovem, também como seu irmão, ao escrever o folhetim, provavelmente com idade entre 17 e 19 anos. No Almanak do Estado de Alagoas de 1891 consta seu nome na lista de funcionários administrativos de Santa Luzia do Norte, como subdelegado do Distrito de Cachoeira e membro do Conselho Municipal, no ano de $1894 .^{12}$

Infelizmente, foram publicados somente 15 capítulos do ensaio, sendo interrompido sem o seu final. O motivo não foi explicado pelo jornal, havendo somente após março de 1884, a publicação de alguns poemas e do folhetim A Sede de Sangue de Carlos Rodrigues, dedicados a seu irmão Valeriano. Em nota introdutória deste seu romance, Carlos Rodrigues dá a entender que o seu irmão estaria comprometido com outras atividades.

(...) Que o digas tu se essas tantas frases com que vou talvez interromper seus teus afazeres sagrados, que o digas se são elas aberração completa do meu espírito. Fiquemos aqui, nenhum resultado fica-me de revelar o que também sente o teu coração e afinal o que sente o coração de todos os alagoanos pobres que acham na literatura a glória do seu viver.

Aprecia, pois, o que te oferece.

\footnotetext{
9 Sobre o Quilombo vários pesquisadores escreveram, entre eles, Arthur Ramos na sua obra O Folclore Negro do Brasil. ${ }_{10} \mathrm{O}$ ORBE. Biblioteca Nacional, Hemeroteca Digital Brasileira. Disponível em: http://memoria.bn.br/hdb/periodico.aspx. Data de acesso: 07/11/2012.

${ }^{11}$ Sobre a família de Valeriano de Souza, pude encontrar no O Orbe alguns dados. Pai: José Felippe de Souza Rodrigues. Mãe: Olympia Cândida de Souza Rodrigues. Irmão: Carlos de Souza Rodrigues, morto em 13/02/1889, com 28 anos, de bronquite (casado com Joaquina Maria Rodrigues, em 1882, perdeu a filha Emilia Maria Rodrigues). Há por razões óbvias muito mais informações no Orbe sobre Carlos Rodrigues, pois esteve por muitos anos, responsável pela tipografia do jornal e colaborando no mesmo com artigos, textos variados, ensaios, poemas. Foi um dos membros fundadores do Montepio dos Artistas juntamente com Pedro Nolasco Maciel.

${ }^{12}$ HEMEROTECA DIGITAL BRASILEIRA. Almanak do Estado de Alagoas, 1891, p. 535 e 1894, p. 321.
} 
O Autor. ${ }^{13}$

Talvez os "afazeres sagrados" a que se refere Rodrigues, se referissem à entrada de seu irmão no seminário. Hipótese ainda a ser verificada. No entanto, o que nos interessa imediatamente é o texto da Caverna do Diabo em si, por seu discurso e representação, ou, "apresentação romanceada" de aspectos da vida social e cultural alagoana. Principalmente, por deixar entrever uma percepção dúbia da intelectualidade local (às vezes valorativa, outras pejorativa) a respeito das "nascentes" religiões afrobrasileiras. A chamada do jornal para o primeiro capítulo do folhetim dizia: "Damos começo ao folhetim do snr. Valeriano de Souza sob o título - A Caverna do Diabo. - Esse trabalho onde se pintam costumes nacionais com toda a propriedade merece a atenção de nossos leitores" (O Orbe, 13 de janeiro de 1884, p. 1). Os "costumes nacionais" indicados pelo redator já sugerem a percepção corrente do espalhamento daquelas práticas religiosas por todo o país, atentando para a "propriedade" com que seriam "pintados". Isto é, o "emprego adequado da linguagem com relação ao que se deve exprimir" ${ }^{14}$. Arrisco a afirmar que seria por um conhecimento in loco da vida religiosa afroalagoana, por parte do autor.

Metodologicamente, para a análise temática proposta, tem-se uma divisão em dois blocos de sentido dos capítulos publicados. O enredo será resumido e a transcrição na íntegra está disponibilizada no site do Laboratório de História Afro-Brasileira. ${ }^{15}$

Resumo do enredo: O ensaio romântico inicia-se com Arthur saindo de Maceió com seu guia Preá para fazer uma viagem de férias pelo interior da província, em dezembro de 1882. Por sugestão de Preá, no caminho, conhece Alexandre, o "Compadre Solitário", vivendo sozinho em uma cabana aos pés da Serra da Barriga. Alexandre lhe conta eventos que teriam se passado em 1813 na Fazenda Galho Seco, de propriedade do Coronel Antonio Coelho, na região de Muricy. Ali se celebrava o retorno do filho Alfredo, formado na escola de Medicina da Bahia. Sua mãe, D. Rosa, esperava que Alfredo se casasse com a filha do Major Porfírio, Amélia; porém, Alfredo estava apaixonado desde a infância por Júlia, filha do Compadre Alexandre. A trama gira em torno, então, dos planos elaborados por D. Rosa para eliminar Júlia ("moça pobre") e garantir o casamento de Alfredo com Amélia ("moça rica”). Alfredo e Júlia contam com o apoio de sua irmã Adélia, e terão como protetores o africano Leopoldo e os escravos da fazenda, principalmente Pai Catumbi e os membros da Casa de Santa Bárbara. Dona Rosa irá contratar os serviços do "feiticeiro" baiano João Caçamba e dos capangas Francisco Giboia e João Pau Santo para assassinar Júlia e Leopoldo. As personagens principais da trama são Leopoldo e

${ }^{13}$ O ORBE. Folhetim A Sede de Sangue. Maceió, 18 de abril de 1884, p. 2.

14 DICIONÁRIO Online de Português. Disponível em: http://www.dicio.com.br/propriedade/. Data de acesso: 18/02/2013.

${ }_{15}$ LAHAFRO. Laboratório de História Afro-Brasileira. Universidade Federal de Alagoas. HTTP://sites.google.com/site/lahafro. 
Dona Rosa. Estes surgem como as oponentes centrais do enredo. São eles que protagonizam os planos que são traçados nos plots.

Como o objetivo principal deste artigo é verificar como os temas da cultura negra e da religião afrobrasileira aparecem no folhetim, os blocos de sentidos temáticos identificados, obviamente, não esgotam outras possibilidades de análise. Para nossos propósitos foram eleitos os seguintes:

1. Práticas religiosas afrobrasileiras. As características pelas quais são apresentadas a cultura e a religião negra por Valeriano de Souza, precisam ser lidas com atenção. Em primeiro lugar, os adjetivos utilizados pelo autor constroem elementos de oposição na qualificação do bem e do mal, como também da personalidade e caráter de suas personagens. Vê-se, a exemplo, a descrição que faz de Leopoldo:

Era Leopoldo, um escravo do coronel. Contava 45 anos de idade, mas a robustez de seus músculos e a ausência de cabelos brancos fazia diminuir-lhe a idade. A tez preta, o rosto um pouco disforme e o achatamento muito pronunciado do nariz faziam ver nele a raça africana. Na verdade Leopoldo era africano. Chegara menino na fazenda do coronel e graças a sua energia e bom comportamento granjeara a amizade de seu senhor. Gosava Leopoldo de algumas regalias era uma espécie de feitor na fazenda. Estimava muito o coronel, amava como se fossem seus filhos Alfredo e Adélia, mas tinha aversão de morte a d. Rosa. O muito desumano com que d. Rosa tratava aos seus companheiros de escravidão agravava cada vez mais o ódio que ele lhe votava. O preto Leopoldo não era como a maior parte dos africanos, estúpido, ao contrário era dotado de grande inteligência. Por uma grande força de vontade muito comum das pessoas inteligentes, aprendera a ler e a escrever com os seus senhores moços Adélia e Alfredo. Por esta superioridade e por seu bom coração era ele estimado e respeitado por seus companheiros. ${ }^{16}$

Percebe-se nesta descrição o que se convencionou chamar o "estereótipo do bom escravo" (Pai João), que a literatura e a ideologia das elites escravocratas alimentaram, com auxílio da educação católica. Todos os elementos "negativados" de Leopoldo (cor da pele, características fisionômicas, etnia) são minimizados a partir de características "não comuns aos africanos": "inteligência". Ter aprendido a ler e escrever o colocaria em um patamar diferenciado de seus outros companheiros de escravidão, assim também como "o amor e devoção que tinha aos seus senhores”. No ensaio, essas características de Leopoldo são reforçadas em vários momentos, e serviriam para marcar tanto a sua superioridade em relação aos outros negros, como a sua liderança entre eles.

${ }^{16}$ O ORBE. Folhetim A Caverna do Diabo. Maceió, 27 de janeiro de 1884, Ed. 7, p. 2. Biblioteca Nacional, op. cit. 
Na luta contra D. Rosa, em favor de seu "senhor moço Alfredo", Leopoldo utiliza-se de sua inteligência para enganar a "sinhá"; mas, para combater os "assassinos" contratados (Giboia e Pau Santo) precisa do apoio de seus aliados na senzala. A religião afrobrasileira surge, pela primeira vez no texto, como se segue:

Em vez de entrar em sua casa que ficava no princípio da senzala, dirigiu-se Leopoldo para outra extremidade e entrou em uma casa, de onde se saiam os desconcertados sons da música dos africanos; ali se dançava. Aproveitando os negros a licença concedida por seu senhor velho, batucavam, festejando a chegada do senhor moço.

Leopoldo, chegando à porta, demorou-se, parecia meditar um pouco. Convém notar que o preto, apesar de ser considerado como chefe naquela espécie de pagode, poucas vezes ali ia. Mas naquela noite, apesar de não ter em vista ir à casa de Santa Bárbara, como chamavam os negros, fora obrigado a isto. Leopoldo sabia que por si só não poderia aparar os golpes que deviam cair sobre a cabeça de Julia; era preciso ter uma polícia ativa que o ajudasse, era o que ia procurar. Sabia o ódio que os companheiros de escravidão tinham de d. Rosa e o amor que os mesmos votavam a Alfredo; era, portanto em seus companheiros que podia encontrar o que precisava. Esperou ainda um pouco, até que o batuque cessou.

Aqui é preciso interromper a narrativa para tecer alguns comentários. Fica claro no texto que a caracterização da música africana e suas danças são apresentadas com estranhamento e/ou desqualificadas. A desqualificação do ritual como "um tipo de pagode" deixa claro que o autor não compreende a religiosidade que tenta descrever. $\mathrm{O}$ costume da permissão por parte dos senhores de batuques e danças dos escravos durantes as festas, nas fazendas e engenhos do Brasil, é conhecido dos historiadores. Serviria como estratégia de controle dos escravizados, minimizando as horas de trabalho, como também passou a ser em muitos casos, parte das atividades de recreio que eram possíveis de gozar a família do senhor e seus convidados. Nas crônicas dos viajantes estrangeiros pelo país, desde o XVII ao XIX são relatados "batuques e pagodes" como o "brinquedo" preferido dos negros. O que importa é perceber nessas danças e batuques a ressignificação da herança religiosa africana e católica, na perspectiva de criação e recriação da ideologia e das práticas religiosas negras. Leopoldo aparece como líder das danças e ao mesmo tempo, desdenha desse costume, já que, por sua "inteligência", estaria em outro nível de "civilização", superior a seus companheiros. Nem sempre, porém, tal costume foi aceito sem problemas. Após as rebeliões dos haussás na Bahia, em 1835, as posturas municipais em Alagoas passaram a proibir os batuques e ajuntamentos de escravos tantos nas vilas, cidades e sítios. Como bem afirmou Laura de Mello e Souza, havia uma associação direta entre quilombo-religião-rebelião que preocupava os senhores. No ensaio de Valeriano, ficou entendido, que este batuque era excepcional, dentro das comemorações de 
retorno do "senhor moço". Por outro lado, toda uma organização própria associativa dos escravos fugia ao conhecimento e controle dos senhores.

Valeriano de Souza pode ter jogado para o passado (1813) características pontuais de um templo afrobrasileiro da segunda metade do XIX. Sabe-se que em Alagoas e em boa parte do Brasil, a católica Santa Bárbara é sincretizada com Iansã e, às vezes, com seu esposo Xangô. Xangô e Iansã são orixás da guerra, do fogo, dos raios e da justiça. Dentro da organização dos candomblés, o orixá que nomeia a Casa é aquele de quem o sacerdote é "filho", ou seja, aquele para quem o sacerdote fez sua iniciação (a "sua cabeça"), ligado a uma ancestralidade por filiação religiosa. Vale lembrar que, os terreiros em Alagoas e Pernambuco são ainda hoje chamados de xangôs, designando o culto, apesar de modo consideravelmente mais restrito em relação ao uso do termo candomblé. Para os pesquisadores, isso sugere a força que tinha o culto ao orixá da justiça Xangô, durante o período colonial e imperial, nesta região. As condições do regime escravista teriam intensificado as necessidades de justiça por parte dos africanos e crioulos. A religião seria utilizada, neste caso, como força espiritual para enfrentamento da realidade. Segue a narrativa do ensaio. Em consideração aos detalhes de funcionamento e caracterização, tem-se uma citação ampliada.

A entrada de Leopoldo causou viva sensação, uma chuva de palmas e gritos onde predominara o dialeto africano foi a saudação de sua chegada. Leopoldo rindo-se fazia festa com todos, depois tomando um aspecto grave disse:

- É preciso nos reunir em conselho, tenho coisa de muito interesse que tratar, as mulheres fiquem na sala enquanto os homens se reúnem na furna do Casumbi*.

- É já, Leopoldo? Pergunta o velho tocador de adufo.

- Sim, sem demora, bem sabem que só negócio me faria vir interrompê-los.

Momentos depois estava reunido o conselho. O que os negros apelidavam de furna do Casumbi era a sala onde se reunia o conselho dos africanos sempre que era preciso tratar de um assunto grave.

Penetremos, pois na furna para assistir ao conselho dos negros.

A sala espaçosa, podia facilmente comportar trinta pessoas. A mobília consistia em um tamborete forrado de pele de raposa sobre um estrado em frente da porta da sala e três grandes bancos de pau encostados às paredes. No início da sala sobre uma estreita e comprida mesa coberta por uma alva toalha viam-se diversos objetos, como fossem pedras, rosários de conchas, mariscos e contas dentro de pequenos pratos, colocados de forma que despertavam logo a atenção. Era a mesa dos feitiços. Leopoldo sentara no tamborete, lugar

\footnotetext{
* Aqui há uma ressalva: neste capítulo aparece o nome Casumbi, enquanto em outro, o nome Catumbi. Ou foi um erro tipográfico, ou o autor, alterou o nome do sacerdote da Casa de Santa Bárbara.
} 
reservado para o chefe e depois de certificar-se que estavam todos, mandou que um só colocasse na porta meio aberta para evitar algum curioso.

- Trata-se de uma coisa grave, disse ele; estou empenhado em um combate em que é preciso viver ou morrer. Não quero por muito tempo ocultar do nosso inimigo, porque não é só por mim que luto, é pela felicidade de todos, é para o bem da fazenda. O nosso inimigo é D. Rosa.

- D. Rosa! Bradaram todos.

- Sim, meus irmãos, é contra esta mulher maldita que quero vosso auxilio. Bem sabem que chegou o nosso bom senhor moço Alfredo, saiu menino e chegou homem. É escusado dizer quanto devemos a este menino que foi criado nos nossos braços; pois bem, querem casar a força o nosso senhor moço matando a noiva que ele escolheu. Leopoldo fez ver aos seus companheiros a conversa que ouvira no jardim da casa grande, nada ocultando dos projetos de D. Rosa.

Os companheiros tremiam de horror.

- É preciso, continuou Leopoldo, tratarmos de aparar os golpes que tem de ferir a boa menina Julia. D. Rosa é capaz de tudo, se tenta em fazer desaparecer a menina Julia, não a deixará enquanto não realizar seus infames projetos; nós bem a conhecemos.

- Sim, Leopoldo, disse o velho tocador de adufo; esta mulher é o diabo que está cá na fazenda, enquanto ela viver as nossas vidas e de nossos filhos não estarão seguras. Sou do teu parecer, formamos um só corpo para melhor bater esta mulher. obedeceremos.

- Sim, sim, bradaram todos; manda, Leopoldo, nós

- Silêncio. Quero um juramento de fidelidade, é preciso muita cautela para sairmos bem da empresa.

Todos se levantaram e colocando a mão sobre a mesa prestaram o juramento de fidelidade, obediência e segredo. Pouco depois continuava o samba interrompido.

Leopoldo não se demorou, precisava de descanso para melhor concertar seu plano de ataque. Caminhando para a casa pairava-lhe nos lábios um sorriso de satisfação. Contava com a vitória, julgava-se forte, tinha o que precisava. ${ }^{17}$

Para o estudioso das religiões afrobrasileiras em Alagoas, este trecho chama a atenção em especial por apresentar, em primeiro lugar, certa "descrição" de elementos de um ritual

${ }_{17}$ O ORBE, Folhetim A Caverna do Diabo, Maceió, domingo, 10 de fevereiro de 1884, Ed. 13, p. 2. Biblioteca Nacional, op. cit. 
religioso no século XIX. A tentativa de descrever em detalhes os elementos do culto, por parte do autor, é entendida como um diferencial naquilo que o editor do jornal chamou de "propriedade para pintar os costumes nacionais". Em segundo lugar, Valeriano de Souza reforçaria em seu texto a marca da africanidade daquela casa no uso do dialeto, na organização em conselho secreto - marca comum das sociedades secretas africanas que funcionaram em todo o Brasil - e na divisão sexual de tarefas, onde as mulheres permaneciam fora do conselho de guerra, uma vez que a proteção do grupo é uma tarefa masculina.

O cuidado em descrever a sala de reunião do conselho ("furna do Casumbi") é esclarecedor. Nos detalhes elencados estão elementos específicos de culto, em que se pode inferir já uma interrelação de elementos sagrados, pedras, rosário de conchas (aqui poderia se referir a um rosário de Ifá) contas, etc. Souza chama de "a mesa dos feitiços", no entanto, sabese que pela posição em que são descritos tais objetos, é mais provável que seja a descrição de um peji, altar com os apetrechos votivos ao orixá cultuado. É claro que não se pode acatar a descrição de Souza como totalmente "correta". Está-se aqui utilizando uma fonte literária que teria, por princípio, o interesse de "pintar" de modo exótico o que, talvez, fosse de conhecimento geral da sociedade maceioense. Ou seja, a existência desses locais de culto africano no estado. Os detalhes dariam a veracidade de sua narrativa e aguçariam a curiosidade dos leitores. Por fim, a representação dada no texto reforçaria a ideia da existência de sociedades secretas de africanos em Alagoas no século XIX e destas estarem profundamente relacionadas às práticas religiosas dos escravizados.

Se, por um lado, tem-se a descrição de um culto organizado, com sua estrutura de rituais e hierarquia, por outro, tem-se a representação extremamente negativada dos chamados "feiticeiros" que atuariam individualmente pela província, atendendo aos objetivos "maléficos" de uma clientela. Valeriano de Souza apresenta a personagem João Caçamba, aliado de D. Rosa, da seguinte forma:

Já havia algum tempo que tinham partido os caçadores, quando parou na porta da casa grande, pedindo esmola, um velho e nojento preto africano. No centro do Brasil aparecem muitos destes miseráveis que se intitulam de feiticeiros. Ao ver esta repugnante figura passou no espírito de D. Rosa uma ideia criminosa. Se este negro pudesse com seus feitiços fazer desaparecer Julia... Estes miseráveis têm às vezes grande número de recursos, experimentemos. D. Rosa deu a esmola pedida e começou a interrogar o africano.

- Então não és destes lugares?

- Não, yaya, venho de muito longe, sou dos sertões da Bahia.

- Anda às esmolas?

- Sim, yaya, sou velho e não posso mais trabalhar. 
- É esta a primeira casa em que pedes esmola? (continua) ${ }^{18}$

- Sim, yaya.

- Para que queres estas ervas?

- É para curar malefício.

- És feiticeiro?

- O que eu faço ninguém desmancha.

- E nesta cabaça o que trazes?

- Uma cascavel, yaya.

- Uma cascavel! E para que uma cobra tão venenosa?

- Porque sou curador de cobra, yaya.

- Ah! Já sei, tiraste o veneno, quebraste-lhe as presas, de sorte que esta cobra já não pode fazer mal; vocês feiticeiros são uns embusteiros.

- Não, yaya, a cobra está com todo veneno e as presas não estão quebradas, a mordedura dela em quem não está curado é morte certa. ${ }^{19}$

Aqui se tem a intensificação do racismo no estereótipo negativo do "negro feiticeiro". E o reforço pelo autor da existência dos mesmos nos interiores do país. Pode-se inferir que Caçamba cumpria funções conhecidas desde o período colonial de praticar curandeirismo com uso de ervas e venenos. De fato, uma das marcas do feiticeiro (nganga ou quimbanda) é poder realizar tanto o bem como o mal; malefícios e benefícios. No texto a personagem surge com as características negativadas, incorpora ainda a acusação de "embusteiro". A prática de curas com ervas era considerada crime do século XIX e até a primeira metade do século XX no Brasil. Charlatanismo sempre foi uma acusação feita contra sacerdotes das religiões afrobrasileiras. Interessante ter sido dado a Caçamba a origem baiana. Por um lado, mostraria a circulação dos negros libertos e ex-escravos pelo nordeste, como também o fato do "escravo velho", não tendo como trabalhar dedicar-se-ia à mendicância ou ao uso de seus conhecimentos mágico-religiosos como forma de sobrevivência. Por outro lado, vê-se certa ideia de que na Bahia haveria feiticeiros poderosos, neste período, reforçando a fama de ter esta província muito da prática religiosa afrobrasileira. O trecho seguinte reforça o estereótipo do uso clientelista dos saberes mágico-religiosos africanos para o mal.

${ }^{18}$ O ORBE, Folhetim A Caverna do Diabo, Maceió, domingo, 10 de fevereiro de 1884, Ed. 13, p. 2. Biblioteca Nacional, op. cit.

${ }_{19}$ O ORBE, Maceió, quarta-feira, 27 de fevereiro de 1884, Ed. 20, p. 2. Biblioteca Nacional, Hemeroteca Digital Brasileira. Disponível em: http://memoria.bn.br/hdb/periodico.aspx. Data de acesso: 07/11/2012. 
D. Rosa formava um projeto diabólico. Se este miserável me vendesse esta cobra e quisesse fazer o que eu lhe ordenasse, o negocio correria melhor do que eu pensava. Nestas matas há muitas destas cobras e ninguém suspeitaria que eu tomasse parte nisto. Uma mordedura de cobra no mato é uma coisa muito comum. Veremos se consigo o que pretendo.

- Então, este animal é ainda muito perigoso? Continuou:

- Sim, yaya, afirmou o preto; está com todo o veneno.

- Se eu quisesse comprar esta cobra, tu vendias?

- Sim, yaya, mas é muito cara.

- Se eu te desse vinte mil réis com a condição de fazeres o que eu mandasse, aceitavas? Caçamba.

- Sim, yaya, mas vossa mercê não dá tanto dinheiro ao pobre

- Quem é Caçamba?

- Sou eu, yaya.

- Engana-te, disse D. Rosa, mostrando um pouco de dinheiro; mas hás de fazer direito o que eu te ordenar.

- Sim, yaya, fale, eu farei tudo quanto yaya quiser, disse o negro, fazendo mil zumbaias. Vinte mil réis paga bem ao pai Caçamba. ${ }^{20}$

Interessa destacar a oposição criada por Souza, entre a figura de Pai Caçamba e a de Pai Catumbi. Apesar de manter um racismo latente nas descrições de ambas as personagens, o fato de utilizar a identificação "Pai" para ambos merece indicação. Tal designação é dada no culto africano e afrobrasileiro ao sacerdote (baba) ou sacerdotisa (iyá) que aprendeu todos os cuidados aos orixás cultuados, conhece todas as orações, cantos, músicas, receitas etc. e que faz a iniciação, criando vários filhos e filhas-de-santo. Nesse sentido, tanto Pai Catumbi quanto Pai Caçamba seriam sacerdotes, com conhecimentos profundos do culto. Segue-se outro trecho:

A fortuna o auxiliava. Apenas Leopoldo havia tomado algum alimento, quando a porta de sua casinha abriu-se e entrou o preto pai José, conhecido na fazenda por pai Catumbi.

- Deus lhe dê boa noite, Leopoldo, disse nesta linguagem própria dos pretos africanos.

- Guarde Deus ao pai Catumbi, respondeu Leopoldo.

${ }^{20}$ O ORBE, Maceió, quarta-feira, 27 de fevereiro de 1884, Ed. 20, p. 2. Biblioteca Nacional, Hemeroteca Digital Brasileira. Disponível em: http://memoria.bn.br/hdb/periodico.aspx. Data de acesso: 07/11/2012. 
- Na casa grande muita novidade, Leopoldo liberto, já não é nosso parceiro. O moleque João, filho do Manoel da tia Benvinda foi quem disse na bolandeira. Tudo está contente porque Leopoldo livrou a menina da morte.

- Sim, pai Catumbi, livrei sinhá Julia e a menina Adélia da morte.

Leopoldo contou toda história que já nós sabemos e concluiu dizendo:

- Virei toda mata e apesar de estar bem certo de ter visto um vulto que fugia por entre as moitas, nada pude encontrar.

- Ah, Leopoldo! Não me enganei, bem fazia eu em desconfiar do diabo do negro, foi ele sem duvida que fez tudo isto, mandado por...

- Que está dizendo, pai Catumbi? Também viu alguma coisa? Perguntou Leopoldo, interrompendo ao preto velho.

- Se vi! Muita coisa vi eu, Leopoldo, e te vou contar toda história. A coisa foi assim: Já fazia bem tempo que você e os brancos tinham saído para a caçada; eu estava conversando com minha mulher Constancia, sentado no estrado defronte da janela do meu mocambo. Dali eu via bem a porta da casa grande. Fazia já um pedaço de tempo que eu olhava quando vi chegar à porta da casa grande um negro velho todo esfarrapado e bateu.

Julguei ao principio que era algum pobre que pedia esmola, mas depois desconfiei. D. Rosa como você sabe não gosta de negro, contudo parecia muito interessada pelo tal negro velho.

Vi D. Rosa dar uma coisa ao tal negro que ficou muito contente pelos gestos que fazia. Desconfiei do tal diabo e esperei que saísse para o seguir. ${ }^{21}$

Pai Catumbi é representado com os mesmos estereótipos do "bom negro". Os modos de falar são caricaturizados tanto quanto os do Pai João Caçamba. Essa característica está presente na literatura romântica brasileira, e também nos artigos de jornais, principalmente, para ridicularizar a figura do negro. No ensaio de Souza, a lealdade de Pai Catumbi ao "senhor" e ao "senhor moço", o respeito à liderança de Leopoldo, o colocam sob bons olhos para o leitor. Nesta ideologia, o lugar social do negro seria o da subserviência, elemento percebido no discurso literário aqui analisado. A indicação do "desgosto" de D. Rosa por negros reforçaria o esquema racista das oposições apresentado por Valeriano de Souza. A atuação conjunta de Pai Catumbi e de dois outros escravos, na história, acarreta na captura de João Caçamba, e encaminha o enredo para dentro da "misteriosa" Caverna do Diabo.

${ }^{21}$ O ORBE, Maceió, sexta-feira, 29 de fevereiro de 1884, Ed. 21, p. 2. Biblioteca Nacional, Hemeroteca Digital Brasileira. Disponível em: http://memoria.bn.br/hdb/periodico.aspx. Data de acesso: 07/11/2012. 


\section{(...)}

Nós nos atiramos sobre ele. Apesar de velho o negro era o diabo. Lançou mão da faca e quis furar Pedro, mas este que é um moleque ligeiro num abrir e fechar de olhos tomou-lhe a faca. Briguemos corpo a corpo, o terreno ficou todo cavado, mas o negro foi amarrado.

- Amarrado! Disse Leopoldo.

- Sim, está bem amarradinho e guardado na gruta da cotia.

- Não perguntasses o que ele andava fazendo?

- Perguntei, mas o diabo não quis responder e não quisemos soltá-lo sem primeiro falar contigo. Assim foi bom porque eu bem sabia que o diabo não andava fazendo boa coisa.

- O pai Catumbi, sem pensar, prestou-me um grande serviço, se o negro escapasse era o diabo. É preciso ia ver o negro e trazê-lo para a caverna do diabo.

- Para a caverna do diabo, Leopoldo!

- Sim, pai Catumbi. Sei que a tal caverna não é muito bem vista para se andar lá de noite; mas por termos a certeza que lá ninguém nos incomoda é que para lá vamos.

- Avise a todos que estiverem no conselho de Santa Bárbara para hoje à meia noite na caverna do diabo. Cuidado que o negro não escape.

- Sim, Leopoldo, farei o que dizes..$^{22}$

Tem-se, pois, neste primeiro bloco de sentido a elaboração de um discurso literário que apresenta a experiência religiosa afrobrasileira do século XIX expressa em duas oposições: (a) a dos cultos organizados - exemplificados na Casa de Santa Bárbara - com hierarquia, apetrechos rituais, batuques, dança e música que mantém uma força associativa através da existência de "conselhos secretos". Estes usam os poderes dos "feitiços", ou seja, expressam as relações de lealdade e filiação religiosa, através do culto à determinada divindade, neste caso, Iansã/Santa Bárbara; e (b) a da ação individual dos "feiticeiros ambulantes", curandeiros e realizadores tanto de "malefícios", como de "benefícios". Os poderes mágico-religiosos quando utilizados para o mal seriam a expressão máxima da selvageria. Dentro da chave de oposições entre "ordem" e "desordem", aparentemente, ficaria para o leitor a impressão de que o negro fora do sistema de escravidão ou subalternização estaria fadado ao crime, seria o "mau negro". Ainda nesse caso, os "brancos maus", como no caso de D. Rosa, se aproveitariam dessas qualidades negativas. Devia ser corrente, entre os alagoanos do XIX, o conhecimento de brancos

${ }^{22}$ Idem, op. cit. 
que faziam uso do trabalho de feiticeiros. Já o "bom negro" protegeria os senhores, manter-se-ia fiel, mesmo no caso de ser liberto - Leopoldo recebe a alforria por salvar a vida de Adélia e Júlia, mas prefere ficar na fazenda como feitor do Coronel - até contra outros negros.

Talvez Valeriano de Souza, como seu irmão Carlos Rodrigues, tenha sido abolicionista ou, pelo menos, simpatizantes do movimento. Em seu ensaio transparece que a crueldade para com os escravos e o "ódio aos negros" seriam características de pessoas ruins. E que, ter a lealdade dos escravos seria derivado de bom temperamento e bom tratamento a eles, de convivência com os negros. A relação casa-grande \& senzala utilizada como paradigma, posteriormente, por Gilberto Freyre, pode ser vista no ensaio. Porém, em nada se aproxima da chamada "democracia racial" uma vez que o lugar social de africanos e crioulos estaria claramente demarcado como subalterno. Isso se explicita quando o autor aborda a temática do Quilombo dos Palmares. No próximo bloco temático vê-se como a demonização do negro aparece relacionada à sua "rebelião".

2. Quilombo dos Palmares e a demonização da herança africana em Alagoas. A narrativa de Valeriano de Souza destaca no interior da província de Alagoas, a região próxima à famosa Serra da Barriga. Os eventos da guerra de Palmares ganharam ao longo do tempo uma forte conotação de identidade local, reforçada na memória através de uma educação oficial que vangloria a vitória das forças contrárias aos quilombos - da "civilização sobre a barbárie". Implicitamente, o leitor de Souza é levado a associar a história do Quilombo dos Palmares, com certas "superstições populares", mantidas por conta da "ignorância" dos sertanejos pobres. Por exemplo, a crença em "assombrações" e na aparição do "diabo". Logo em seu primeiro capítulo, Preá, o guia de Arthur conta-lhe um "causo" de quando se deparou com o diabo.

(...) - Então, o que temos, senhor Preá?

- Aqui mataram um ladrão.

- O que tem isto?

- É mal assombrado.

$-\mathrm{Ah} !$

- Sim, senhor Arthur, eu já dei também minha carreirinha daqui.

- Então encontrou-se com a alma do ladrão?

- Ou com o diabo, senhor Arthur.

- Com o diabo!

- Sim. Eu lhe conto como foi o negocio. Foi no mês de junho, numa sexta-feira. Era noite de lua, eu tinha saído de casa com minha 
carga de farinha bem cedinho para vender em Maceió. A Quitéria, minha mulher, que já sabia que este lugar não é bom, porque um tio dela já daqui correu, me preveniu que chegasse cedo ao Tabuleiro, não passasse esta maldita Mata do Rolo à noite. Eu era valente, senhor Arthur, não fiz caso do que me disse a mulher. Cheguei ao Curralinho ao meio-dia, descansei, soltei o cavalo e só a boquinha da noite montei a carga e toca para dormir no Tabuleiro.

Todo caminho fui bem, mas ao chegar a este maldito lugar os cabelos arrepiaram, a terra tremeu e um vulto negro do tamanho daquela sicupira que senhor vê, traz! Saltou em cima do meu pobre melado.

Eu não tive medo, puxei da faca e saltei em cima do maldito vulto. Mas, ah! Senhor Arthur, quando o maldito virou-se para mim, deitando fogo pelos olhos, pelas ventas, pela boca e pelos ouvidos e me gritou com medonha: - Preá, Preá eu te levo; não tive mais animo, deitei a correr para traz e fui cair, sem fala, no Curralinho.

Quando tornei, não soube de meu cavalo, por mais que o procurasse nunca o pude encontrar. Supunha que o diabo não contente com a farinha levou também o meu pobre melado.

O pobre do Preá tremia como varas verdes e eu ria-me a custa do pobre homem. ${ }^{23}$

Até hoje a Mata do Rolo é local cercado de histórias. Durante o período da República Velha, foi lugar para a prática clandestina das religiões afrobrasileiras, perseguidas pela polícia naqueles anos. Arthur não acredita em Preá, e pensa que este foi enganado por algum ladrão esperto. No estereótipo do sertanejo, as superstições, crenças em fantasmas, bruxas e feitiços teria um papel importante para a explicação dos "mistérios do mundo". A oposição aqui é aquela entre o "moço estudado da cidade" e o "sertanejo pobre", limitado em seu mundo. Valeriano de Souza vai, em sua literatura, associar diretamente, através de descrições e adjetivos, o diabo avistado por Preá na Mata do Rolo àqueles outros que habitariam a Caverna do Diabo.

A Caverna do Diabo, no texto, é uma "furna ao pé da Serra da Barriga". Não se sabe se tal caverna realmente existiu. Na região de Muricy, até os dias atuais, há muitas cavernas próximas a Serra da Barriga, abertas à visitação turística. Segundo Valeriano de Souza, em 1884, existia "esta caverna no lugar chamado Jurema". Como criação literária a caverna cumpre a função de ser um espaço "perigoso" em vários sentidos e para diferentes usos no enredo. As confluências das tradições africanas, europeias e indígenas são percebidas a seguir:

A caverna do diabo era o nome que se dava a uma furna na base da serra do barriga. Existe hoje esta caverna no lugar chamado Jurema. No

${ }^{23}$ O ORBE, Folhetim A Caverna do Diabo, Maceió, 13 de janeiro de 1884, Ed. 1, p. 2. Biblioteca Nacional, op. cit. 
tempo em que se deram as cenas que narramos não gosava a caverna de boa reputação. Diziam que era a moradia constante do diabo. Se pelo dia alguém se aproximava da caverna era tomado de um terror desconhecido e tentava afastar-se daquele lugar diabólico. Ao anoitecer não havia quem se atrevesse a aproximar-se dela. Alguém afirmava que já havia visto os diabos reunidos em conselho na caverna. Pintavam Lúcifer um negro corpulento de um tamanho desproporcional, com os olhos injetados de fogo, deitando brasas pela boca, tendo dois chifres retorcidos na testa, pés de pato e outras coisas filhas da superstição grosseira de um povo não civilizado. Não eram só os diabos que faziam suas reuniões na caverna, os feiticeiros também lá iam quando queriam invocar os espectros das trevas para seus feitiços. Muitos negros da fazenda do coronel eram mal vistos pela vizinhança, e acusados de terem relações íntimas com os diabos. Alguns negros tinham sido vistos dirigirem-se para o lado da caverna e isto bastou para que fossem logo espalhadas as relações deles com os diabos. Sabiam os negros disto e pareciam alimentar esses boatos.

A caverna do diabo, guardada como estava pela superstição do povo, era um ponto de refugio para os negros fugitivos. ${ }^{24}$

Interessante descrição. Valeriano de Souza apresenta as superstições locais do período em torno da caverna, ou as inventa? Tanto em um caso como no outro, importa-nos a elaboração ou reelaboração de mitologias culturais diferentes e da clara associação entre práticas mágico-religiosas europeias, africanas e indígenas. Ora, Jurema é termo conhecido das religiões afroalagoanas através da confluência com as tradições indígenas. Estas fazem amplo uso do chá dessa planta, para fins de cura mística e contato com mestres espirituais. O culto à Jurema Sagrada no Nordeste está entrelaçado aos cultos afrobrasileiros. Em Maceió, algumas casas de axé, nagô, angola e outras, têm dias reservados no calendário de festas para a celebração do culto à Jurema Sagrada.

A caverna, ao ser apresentada como moradia constante do diabo, talvez possa ser compreendida como um local real que foi utilizado pelos quilombolas para se esconder nos momentos de perseguição, como também para a realização do culto por escravos em que o transe místico ocorresse. A fama negativa adviria da educação católica que associava constantemente, as práticas africanas e indígenas, como "obras do demônio". Principalmente, o transe religioso ficou marcado para a mentalidade católica como "possessão demoníaca". No texto, os orixás estariam, nesse caso, "demonizados", e o seu transe extático, visto como uma "relação íntima com os diabos". A demonização do Outro e sua cultura (indígena, africano) fazia parte do processo de evangelização e extermínio de outras "forças profundas da alma coletiva" (Bastide), somadas à desorganização da vida material daquelas populações. $\mathrm{O}$ fato de $\mathrm{o}$ autor ter

24 O ORBE, Maceió, domingo, 2 de março de 1884, Ed. 22, p. 2. Biblioteca Nacional, Hemeroteca Digital Brasileira. Disponível em: http://memoria.bn.br/hdb/periodico.aspx. Data de acesso: 07/11/2012. 
associado o medo advindo dessas práticas a uma estratégia de proteção para "os negros fugitivos", indicaria a relação estabelecida pelas elites e brancos, entre a prática da religião negra e a fuga e rebelião escrava. É possível, que este medo tenha sido alimentado, como também seria possível, que os senhores, preocupados sempre com a rebelião e a fuga de escravos, vissem na aglutinação dos negros e na sua religião, um elemento perigoso para a ordem. Isso porque esboçaria uma realidade que escapava das lógicas do escravismo e da ideologia branca, com seu código e sistema próprio, "misterioso e secreto" para aqueles que dela não compartilhavam.

Pode-se, incluir, uma análise interna, cultural, das características levantadas no texto. A descrição do diabo, destacada na citação, necessita ser desconstruída. O texto de Valeriano de Souza, independente de sua qualidade estética, enquadra-se dentro da literatura romântica do século XIX. No entanto, a sua descrição do diabo parece carregar elementos do período moderno. A figura do diabo é uma criação do cristianismo, a partir da ressignificação da simbologia e mitologia de outros povos. No processo de expansão histórica do cristianismo e do catolicismo, os demônios foram adquirindo as qualidades e características dos "deuses vencidos".

A palavra diabo deriva do grego diabolos, significando "caluniador, provocador de discórdia”, traduzido como satã no hebraico. Na doutrina cristã, seriam os "anjos que se rebelaram contra Deus", especialmente o mais elevado entre eles, Lúcifer, que seduziu o primeiro casal humano ao pecado e, desde então, é o "príncipe do mundo". "No cristianismo antigo o diabo era representado como serpente, dragão, leão, basilisco, áspide; no século IX como anjo negro nu; a partir do século XI até o século XVI sua representação evoluiu para demônios hermafroditas fantásticos, grotescos, semelhantes aos sátiros". "Na renascença italiana e no barroco predomina a forma humana do diabo. A partir do século XIX observa-se "crescente psicologização" de sua figura. Já o termo demônios, do grego daimon, foi em sua origem a "designação de deuses", depois de "seres intermediários entre deuses e homens, que podem influenciar os destinos humanos e os eventos cósmicos para o bem e o mal". Os filósofos gregos os consideravam "a parte divina ou a voz divina no homem (daimonion)". Eles se caracterizariam "pelo seu modo de ser imprevisível e caprichoso e frequentemente se apoderam das forças psíquicas dos homens". A tradição bíblica "descreve-os exclusivamente como espíritos maus, anjos decaídos, que representam um poder contra o domínio de Deus”, portanto, de desordem. Aparecem como "seres sobre-humanos, gigantes (são demonizados, nas lendas muitas vezes, bobos e cômicos), anões (recebem traços humanos, sendo ferreiros habilidosos, por vezes representam normas éticas superiores) e como seres extra-humanos”. Por último, Lúcifer (Lucifero = portador da luz), era o mais elevado anjo que se rebelou contra Deus. No imaginário germânico, era aquele que traz o fogo diabólico. 25

${ }_{25}^{2}$ DICIONÁRIO DE SÍMBOLOS. Verbetes Diabo e Lúcifer, p. 88; 173. 
Essas explicações de elementos da mitologia cristã ajudam a entender a força da representação do medo, das "forças demoníacas" que atuariam no mundo. Segundo Valeriano de Souza, essas superstições seriam resultado da ignorância (falta de educação formal). Tal perspectiva encontra eco no avanço das ciências no século XIX, em especial, a partir de uma visão iluminista e positivista do mundo. Ao alocar essas representações míticas no plano das crenças populares, o autor, induz ao leitor a ideia de que as práticas religiosas africanas ou negras fariam parte também deste universo das superstições. Sabe-se que, por muito tempo - e infelizmente, ainda hoje - o reforço dessa argumentação pesou para a continuidade histórica das religiões afrobrasileiras. Justificou toda sorte de violência e reforçou políticas que mantiveram a população negra subalternizada no país.

Outro aspecto problemático desta representação é a demonização do negro em si, através da associação de sua cor de pele como a mesma do diabo. Em todo o Ocidente, sob influência do regime escravista, o estereótipo racista foi reforçado ao extrapolar as características fenotípicas do negro como "feio", "pavoroso", "grotesco", etc. No texto, Souza deixa entrever de modo indireto essas construções.

Leopoldo dirigiu-se para a caverna do diabo onde os companheiros o esperavam. Um pavio embebido em cera de abelhas iluminava o recinto da caverna. O seu interior que gosava de tão má reputação nada tinha de horroroso; e se alguma coisa apresentava um cunho de pavoroso era de certo o estranho conselho dos negros que funcionava naquele momento esclarecido pela mortiça luz de tão mesquinho candeeiro.

Se algum dos moradores da fazenda se aproximasse da caverna, de certo fugiria espavorido, julgando ter visto uma reunião de diabos. As sombras cercando de todos os lados não deixavam ver o interior da caverna. Mas, como não era a primeira vez que a curiosidade nos tinha levado ali, podemos fazer aos leitores uma rápida descrição.

Formava a caverna uma ampla sala, mas de forma irregular, a semelhança de um perfeito polígono octógono irregular. A área deste polígono era alguma coisa obstruída por grandes pedras, mas postas pela natureza com tal arte, que a primeira vista apresentavam o aspecto de um salão mobiliado. As paredes fendidas em diversas partes apresentavam nas rochas denegridas pelo tempo saliências verdadeiramente fantásticas que para os espíritos fracos passariam por verdadeiras figuras diabólicas dispostas de maneira a tornar medonha aquela habitação infernal. No fundo da caverna notava-se uma abertura em forma de porta que dava entrada para uma segunda caverna; mas esta era tão escura que mesmo a luz de um facho não teria poder de espancar as trevas. 
Leopoldo sentou em uma das pedras que ornavam o interior da caverna e os outros o imitaram. Foi apresentado o miserável negro que já conhecemos e principiou uma espécie de interrogatório. ${ }^{26}$

A associação direta entre a figura do negro e a do diabo no trecho é complementada por uma descrição da caverna. Nela o narrador "racionalmente" explica ao leitor suas características, retirando todo o mistério daquele ambiente. No enredo, a caverna é utilizada por Leopoldo e seus companheiros para interrogar João Caçamba. As maldições proferidas pelo velho feiticeiro marcariam, novamente, a oposição entre os "bons escravos" e os "maus". Também a uma "força demoníaca”, neste último caso, favorável a Leopoldo e seus companheiros. Não importando a quem, o demônio é sempre o Outro.

Depois de longa conferência os negros deliberaram que fosse conduzido o miserável negro velho para fora da cidade e posto em liberdade.

João Caçamba logo que se viu livre em lugar de se afastar da fazenda ocultou-se em uma moita a fim de enganar os seus perseguidores, e logo que estes se ausentaram voltou, e internou-se nas matas da fazenda.

- Ah, malditos negros! Canalhas! Resmungava ele; hei de vingar-me, não se brinca assim com o Caçamba, breve os diabos carregarão vocês todos, corja miserável. Conto a D. Rosa o que se passou e o diabo há de ter dó do couro dos negros.

Mas oh! Diabo, se yaya não acreditar que eu fiz o serviço? Nada, ela bem devia ter sabido, se não fosse o malvado do negro que me estava interrogando, todo soberbo, na caverna do diabo, o negocio tinha corrido bem, portanto não foi culpa minha. O que eu quero é o dinheiro que ainda me deve. Safa! O negocio não foi de caçoada, escapei de boa rascada. Se os diabos quisessem eu lá ficavam enterrado na caverna do diabo. Bem empregado o nome, é um lugar dos trezentos. Não eu que fosse lá. (continua) ${ }^{27}$

Este segundo bloco temático permitiu perceber que certa literatura romântica em Alagoas, no século XIX, utilizou-se das práticas religiosas afro-brasileiras como tema que exemplificava as superstições populares, existentes no interior da província. Ao mesmo tempo em que se percebe a continuidade de mitologias e simbologias do cristianismo medieval e moderno, vê-se essas representações associadas às religiões afrobrasileiras. Há, por outro lado, um reforço racista nas concepções apresentadas, nas quais o negro e o demoníaco são diretamente associados. Apesar da dubiedade em que aparece essa associação, uma vez que o diabo tanto

${ }^{26}$ O ORBE, Folhetim A Caverna do Diabo, Maceió, domingo, 9 de março de 1884, Ed. 25, p. 2. Biblioteca Nacional, Hemeroteca Digital Brasileira. Disponível em: http://memoria.bn.br/hdb/periodico.aspx. Data de acesso: 07/11/2012. ${ }_{27}$ Idem, op. cit. 
pode fazer o mal como o bem, talvez isso sugira que a própria condição do negro na província, naquele momento, estava em situação transitória, uma vez que a atuação abolicionista e a própria resistência escrava, através das fugas e alforrias, se mostravam mais constantes.

\section{CONSIDERAÇÕES FINAIS}

Uma interpretação histórica mais ampla sobre as relações étnico-raciais e os lugares sociais do negro em Alagoas, no período pós-Abolição, ainda está sendo construída. Tem sido de grande valia a busca por fontes de pesquisa, seu elencamento e divulgação. Estes e irão contribuir para o mapeamento do avanço do processo de elaboração da cultura negra local e do papel, de fato civilizatório, que os sujeitos negros desempenharam naquele estado.

O Brasil tem avançado, mesmo que a passos lentos, na afirmação de seu caráter identitário negro-africano. As ações afirmativas através da aplicação de políticas públicas de reconhecimento, proteção e valorização da negritude vão alcançando novos espaços sociais. $\mathrm{O}$ racismo à brasileira converteu-se em um mecanismo de reforço de alienação, muito favorável ao sistema capitalista. Portanto, sua desconstrução ideológica, criminalização e punição de suas práticas encontram ainda resistências estruturais e de classe; em grande medida devido à manutenção da exploração da força de trabalho da população negra.

Alagoas é um dos estados brasileiros com o maior contingente de população negra e parda. O histórico de violência contra esta população é sistêmico, chegando às raias do patológico. Partindo-se de dados sociais, nota-se que esta não é uma afirmação exagerada. Cabe aos historiadores da cultura negra e das relações étnico-raciais no Estado, lidarem com a crua realidade deste presente. São estas as questões que nos levam a refletir historicamente sobre os períodos anteriores.

Viu-se que a organização de cultos afrobrasileiros em Alagoas data, pelo menos, de início dos oitocentos, tendo raízes muito mais antigas. O ensaio de Valeriano de Souza oferece, para além do racismo ou pouca qualidade literária, uma imagem que ajuda a elaborar algumas hipóteses sobre a organização e presença da religiosidade negra na região.

Em primeiro lugar, o fato de esta religiosidade ter-se constituído mesmo nas condições adversas da escravidão - questão comummente indicada pelos especialistas. Além disso, os estudiosos têm dado cada vez mais importância à "africanização" do cristianismo dos senhores de engenho e suas famílias, admitindo que esta tenha sido mais significativa do que se previa até então; invertendo, consequentemente, a tradição interpretativa que privilegia a "cristianização" das religiões africanas. $\mathrm{O}$ controle estabelecido pelos brancos às práticas negras parece ter tido 
eficácia limitada, uma vez que a mesma elite que as controlava e as perseguia acabava delas fazendo uso e nelas tendo fé e filiação.

Em segundo lugar, nota-se que a grande violência do racismo contra as religiões afrobrasileiras no estado de Alagoas se deu justamente em resposta à grande importância e força da presença negra ali, evidenciada pela própria repressão. Ou seja, quanto mais ameaçada por tamanha força se sentia a elite, mais mecanismos de inferiorização e controle eram estabelecidos, como, por exemplo, os discursos que saiam dos salões do IHGAL, com destino às escolas, imprensa e púlpito - locais de predominância do papel “educador” da Igreja Católica.

Por fim, as oposições ideológicas percebidas no texto de Valeriano de Souza, nos informam de dois planos de desenvolvimento para a religiosidade negra: (a) o caminho do culto coletivo, e (b) a prática individual da feitiçaria.

Tais caminhos não teriam se distanciado e se oposto de modo total, uma vez que dentro dos cultos, ambas as esferas funcionavam conjuntamente: o "feiticeiro" também frequentava e/ou pertencia a casas de culto. Porém, ao apresentar tal oposição no texto, qualificadas de bem e mal (ou tendenciosamente bom ou mal) o autor parece se aproximar de uma realidade interna à ideologia negro-africana. Para esta, de modo geral, a feitiçaria pode funcionar como força de anomia social e dissociação quando praticada para fins individuais, enquanto os rituais religiosos coletivos, para fins de louvação, possuem força de aglutinação das energias do grupo, e reforçam as relações interpessoais e de solidariedade.

Bastide, entre outros, via nessas diferenças as marcas das influências centro-africanas (bantu), de tendência individual; e africano-ocidental (iorubá-nagô) de tendência coletiva; conjugadas às práticas indígenas e ao catolicismo popular. Mas, o universo bantu não é desconhecedor do papel social coletivo das práticas mágicas. Talvez, o caráter de especialização de seus agentes religiosos - como no caso do quimbanda ou do nganga - tenha levado a tal conclusão. Pois, uma vez que a ideologia religiosa bantu é mais antiga na colônia, misturou-se, gerando um sincretismo mais significativo. Além disso, a presença de um "feiticeiro baiano", ainda pode ser aproveitada para se pensar na circulação dos saberes mágico-religiosos pelo nordeste brasileiro, como também na disputa e concorrência entre os axés.

\section{REFERÊNCIAS BIBLIOGRÁFICAS E FONTES}

ALMEIDA, Luiz Sávio de (org.). Traços e Troças: literatura e mudança social em Alagoas. Estudos em homenagem a Pedro Nolasco Maciel. Maceió: Edufal, 2011.

AVÉ-LALLEMANT, Robert. Viagens pelas províncias da Bahia, Pernambuco, Alagoas e Sergipe (1859). Belo Horizonte/São Paulo: Editora Itatiaia e Edusp, 1980.

AZEVEDO, Célia Maria Marinho de. Onda negra, medo branco. O negro no imaginário das elites, século XIX. São Paulo: Annablume, 2004. 
CARDOSO, Ciro Flamarion; VAINFAS, Ronaldo (orgs.). Domínios da História. Ensaios de Teoria e Metodologia. 21 a Tiragem. Rio de Janeiro: Elsevier, 1997.

BASTIDE, Roger. As religiões africanas no Brasil. $3^{\mathrm{a}}$ edição. São Paulo: Livraria Pioneira Editora, 1960.

DIÉGUES JÚNIOR, Manuel. O Bangüê das Alagoas: traços da influência do sistema econômico do engenho de açúcar na vida e na cultura regional. Maceió: Edufal, 2012.

FREYRE, Gilberto. O escravo nos anúncios de jornais brasileiros do século XIX. $4^{\text {a }}$ edição revista. São Paulo: Global Editora, 2010.

GALVÃO, O. E. A.; ARAÚJO, T. V. COMPILAÇÃo das Leis Provinciaes das Alagoas - de 1835 a 1870. Vol. 1, e Vol. 2. Maceió: Typographia Comercial de A. J. da Costa, 1870.

INSTITUTO HISTÓRICO E GEOGRÁFICO DE ALAGOAS. Viagens de José Bento da Cunha Figueiredo Junior à Província das Alagoas. Maceió: Grafmarques, 2010.

MACIEL, Osvaldo (org.). Pesquisando (n)a Província: economia, trabalho e cultura numa sociedade escravista (Alagoas, século XIX). Maceió: Editora Gráfica, 2011.

MOURA, Clóvis. Dicionário da escravidão negra no Brasil. São Paulo: Edusp, 2001.

O ORBE. Várias edições de 1884. Hemeroteca Digital Brasileira. Fundação Biblioteca Nacional. Disponível em: http://hemerotecadigital.bn.br/. Data de acesso: 17/12/2012.

RAFAEL, Ulisses Neves. Xangô Rezado Baixo: religião e política na Primeira República. Maceió/Aracaju: Editora UFS/Edufal, 2012.

SANT'ANA, Moacir Medeiros de. História da Imprensa em Alagoas. Maceió: Arquivo Público de Alagoas, 1987.

SANT'ANA, Moacir Medeiros de. Contribuição à história do açúcar em Alagoas. Edição fac-simile. Coleção Pensar Alagoas. Maceió: Imprensa Oficial Graciliano Ramos, CEPAL, 2011.

SOUZA, Laura de Mello e. O Diabo e a Terra de Santa Cruz: feitiçaria e religiosidade popular no Brasil Colonial. $2^{\text {a }}$ edição. São Paulo: Companhia das Letras, 2009. 